\title{
How can scientific information on the Okavango Region be made useful for decision making? - An integrated compilation of the first products of the project "The Future Okavango"
}

\author{
Norbert Juergens
}

\begin{abstract}
Introduction
Natural resources and services provided by ecosystems are getting more and more limited while the demand for land, water and ecosystem services is globally growing (Millenium Ecosystem Assessment 2005). Therefore, the old style of land use planning driven by opportunity and short lived interests is no longer a valid option. Instead, knowledge based decision making shall allow to combine prosperous development with sustainable use of resources and conservation of biodiversity and ecosystems. To support this goal, the project "The Future Okavango" has been developed within the frame of a global program on "Land management" (LaMa) established by the German Federal Ministry of Education and Research (BMBF) in 2010.
\end{abstract}

"The Future Okavango" focusses on the large catchment of the Okavango (Cubango) river network that encompasses wide areas of Angola, Namibia and Botswana. This catchment forms a very interesting system because it ends up in the globally reknowned Okavango Delta that forms an endorheic basin and makes changes in the water flow that reaches the Delta highly visible. Within the large basin almost all the problematic issues take place that are presently changing the surface of the African continent, including demographic growth, deforestation, increasing use and pollution of water, to name just a few. Therefore, the results and experiences generated by "The Future Okavango" will also be transferable to and applicable in other regions of Africa. For achieving its goal the project also had to compile a wide array missing baseline data, especially in the war ridden parts of SE Angola.

"The Future Okavango" project assesses important ecosystem functions and services and their valuation within the Okavango basin. It explores and projects related processes of change and identifies tradeoffs and thresholds that are highly relevant for the future development of the region. Scenarios of potential future development pathways are identified encompassing the international and the local perspective. Governance instruments are analyzed from the local to the transnational scale, including OKACOM (Pinheiro et al. 2003).

From the beginning, "The Future Okavango" used a trans-disciplinary approach and work was planned and implemented in close cooperation with a wide range of decision makers in the region. In the future years, the products of the project will become available for the stakeholders. One of the most important preconditions to turn this vision into reality is to organize access to the relevant information, i.e. useful information that allows stakeholders to take informed decisions.

There is a wide range of different types of "information", ranging from raw or processed data - interesting for scientists - to guidelines and recommendation for practitioners in the different fields of land use and resource management. While each of these types of information is of value to some users it is most important for all users to rapidly find the most suitable information. Therefore, the first batch of such information for decision makers and for scientists presented in this Special Volume of the journal „Biodiversity \& Ecology“ is subdivided into "Fact sheets", "Conceptual papers" and "Research Articles".

\section{Fact sheets: Overview and Local scale}

As it fits to a first series of products this Special Volume first of all delivers baseline data. It will be important for all involved players to understand and make use of these baseline data whether they are at the catchment scale or at the local scale. At the catchment scale it is very important to learn about the degree of spatial and temporal heterogeneity. For valid assessments at local scale it is necessary to be able to compare at least among the four core research sites. For both scales the information is presented in the straightforward format of "factsheets". Therefore, the Special Volume starts with a series of six overview factsheets describing the whole Okavango basin with regard to its physicgeographical settings, the climate, the hydrology, the land cover and remote sensing analyses, the vegetation, and the relative importance of ecosystem services for stakeholders.

The overview is followed by four series of local baseline factsheets providing data and information on the four Core Research Sites of the TFO project, located at Cusseque and Caiundo in Angola, at Mashare in Namibia and at Seronga, in Botswana. The usual sequence of papers deals with the landscape structure, the climate, the soils 
and soil fertility, the contributions of microbiology, the earth observation viewpoint, the vegetation, the people and always a special presentation of the projects local para-ecologist.

In addition to this regular sequence, there are a few products from special efforts that could be established at specific sites. Examples are a look at micro-climatic conditions, and the use of woody plants, both at Cusseque, a report on the diversity of birds, at Cusseque and Caiundo, and a special approach to the diversity of the micro-algae in the Okavango Delta.

\section{Conceptual papers - scientific approaches}

In addition to the supply of baseline information (factsheets) it is necessary to explain the scientific concepts around ecosystem services as used and applied in the TFO project.

One concept paper (Roeder et al. 2013) deals with the multitude of spatial and temporal scales and cumulative effects that need to be considered when assessing ecosystem functions and services and use of these. A second contribution (Domptail et al. 2013) looks at the trade-offs and synergies that need to be considered when dealing with ecosystem services and resource management in a context of human well-being. A third article (Schmidt et al. 2013) addresses the challenges of transdisciplinary research in theory and practice, also presenting the instruments used to interact with the diverse stakeholder groups. A fourth conceptual paper (Kralisch et al. 2013) presents the TFO approach to a data and information management that is useful for both, scientists and stakeholders.

\section{Research articles}

The main body of the Special Volume is dedicated to a series of sixteen research articles. These are again sorted in a series starting with aspects of the landscape, followed by climate, hydrology, the importance of water for ecosystems and livelihoods, agricultural yield assessments, the role of soil bacteria and phosphate and soil fertility, recent land use change, floodplain vegetation, riparian tree species, fire regime, livelihood diversification, household economies, land utilization strategies, and customary water law.

These articles offer a wide range of first products. It is impossible to mention all the products here. However, the reader will be interested to find a lot of novel information regarding for example a modern approach to the basins landscape classification based on relief (Wehberg et al. 2013), a first analysis of the water flow dynamics within the Okavango and its main tributaries (Steudel et al. 2013), a time series analysis of land use and land cover changes within the Angolan part of the basin since the end of the civil war (Schneibel et al. 2013), to name just a few.

In summary, this Special Volume of „Biodiversity \& Ecology“ offers a first integrated compilation of the biophysical setting, the most important processes of change as well as the main interactions between the various stakeholder groups and their environment.

We hope that this book will serve many stakeholders in their pursuit of taking the right decisions for sustainable and efficient use of the natural resources and the conservation of these resources for the long-term functioning of the ecosystems and the long-term well-being also of the future generations.

\section{References}

Domptail, S.E., Nuppenau, E.-A., Azebaze, N., Brown, L.D., Falk, T., Finckh, M., Große, L.M., Kowalski, B., Pröpper, M., Stellmes, M., Overmann, J. (2013): Using trade-offs and synergies in ecosystem services in resource management. - Biodiversity \& Ecology 5: 185-193. CrossRef

Kralisch, S., Zander, F., Flügel, W.-A. (2013): OBIS - a Data and Information Management System for the Okavango Basin. - Biodiversity \& Ecology 5: 213-220. $\underline{\text { CrossRef }}$

Millennium Ecosystem Assessment (2005): Ecosystems and Human WellBeing: Our Human Planet: Summary for Decision Makers. Vol. 5. Island Press.

Pinheiro, I., Gabaake, G., Heyns, P. (2003): Cooperation in the Okavango River basin: The OKACOM perspective. In: Turton, A., Ashton, P. [Eds]: Transboundary rivers, sovereignty and development: hydropolitical drivers in the Okavango River basin. 105-118. African Water Issues Research Unit, Pretoria

Röder, A., Stellmes, M., Domptail, S.E., Eschenbach, A., Finckh, M., Gröngröft,
A., Helmschrot, J., Pröpper, M., Schneibel, A., Stoffels, J. (2013): Cumulative effects of policy and management actions on ecosystem services. Challenges and methodological approaches in The Future Okavango project. - Biodiversity \& Ecology 5: 167-183. CrossRef

Schmidt, L., Domptail, S.E., Gruber, M., Klintenberg, P., Schmiedel, U., Zimmermann, I., Falk, T. (2013): Transdisciplinary research and stakeholder involvement. A review of the TFO approach. - Biodiversity \& Ecology 5: 195-212. CrossRef

Schneibel, A., Stellmes, M., Revermann, R., Finckh, M. (2013): Agricultural expansion during the post-civil war period in southern Angola based on multi-temporal Landsat data. Biodiversity \& Ecology 5: 311-319. CrossRef

Steudel, T., Göhmann, H., Flügel, W.-A., Helmschrot, J. (2013): Assessment of hydrological dynamics in the upper Okavango River Basins. - Biodiversity \& Ecology 5: 247-261. CrossRef

Wehberg, J., Bock, M., Weinzierl, T., Conrad, O., Böhner, J., Stellmes, M., Landschreiber, L. (2013): Terrain-based Landscape Structure Classification in Relation to Remote Sensing Products and Soil Data for the Okavango Catchment. - Biodiversity \& Ecology $\mathbf{5}$ : 221-233. CrossRef

\section{Affiliation}

Norbert Juergens*

(norbert.juergens@t-online.de)

Biodiversity, Evolution and Ecology of

Plants, Biocentre Klein Flottbek and

Botanical Garden, University of

Hamburg

Ohnhorststr. 18

22609 Hamburg, GERMANY

*Corresponding author 